\title{
CZY TYLKO PARYŻ? KILKA UWAG NA TEMAT POLSKICH ARTYSTEK NA POŁUDNIU FRANCJI
}

\author{
Marta CHRZANOWSKA-FOLTZER (Francja)
}

Polska obecność artystyczna na południu Francji jest zjawiskiem wciąż jeszcze zbyt mało znanym w naszej historii sztuki. Twórczość polskich malarzy związana z obszarem śródziemnomorskim jest traktowana nie jako zjawisko, lecz częściej, jako epizod w dorobku poszczególnych artystów i jako taka przedstawiana w opracowaniach i katalogach. Na południu Francji nie występowały zjawiska porównywalne do powstałej w Bretanii kolonii artystów polskich. Brak było miejsc szczególnej koncentracji artystów w danym okresie, na miarę bretońskich miejscowości Pont-Aven, Doëlan czy Le Pouldou. Spotkanie z południem należało bowiem do doświadczeń bardzo indywidualnych, rozłożonych w czasie, będących udziałem niewielkich grup artystów, takich jak na przykład kapiści. Dlatego można z pewnością napisać historię sztuki polskiej wykluczając lub redukując do kilku przykładów polskie doświadczenia artystyczne u wybrzeży Morza Śródziemnego. Pozostaje jednak olbrzymi zespół dzieł o inspiracji śródziemnomorskiej, wielki dorobek polskich twórców, imponujący pod względem rozmiarów, jak i poziomu artystycznego. W kolekcjach muzealnych, w galeriach i w zbiorach państwowych lub prywatnych, zarówno polskich, jak i francuskich znajduje się duża liczba polskich dzieł związanych z południową Francją. Zbiór ów zmusza historyka sztuki do postawienia pytań o genezę, historię i o znaczenie owego dziedzictwa, które zrodziło się z podróży artystycznych polskich twórców na śródziemnomorskie, francuskie wybrzeże. W tym dorobku szczególne miejsce zajmują dzieła kobiet.

Do postawionego w tytule pytania dorzucić można jeszcze i to: czy tylko Bretania? Poza paryskim środowiskiem artystek polskich, bardzo szczegółowo opracowanym przez historyków sztuki, jedynie grupa malarek tworzących w Bretanii doczekała się 
opracowania i znalazła godne miejsce na wystawie pokazującej dorobek tamtejszej artystycznej kolonii polskiej z lat 1890-1939 ${ }^{1}$.

Należały do niej Anna Bilińska-Bohdanowiczowa, Olga Boznańska, Karolina Grabowska, Maria Ewa Łunkiewicz-Rogoyska oraz Mela Muter.

Studia nad śródziemnomorskim dorobkiem polskich artystów pozwoliły mi stwierdzić, że wiedza dotycząca karier malarek polskich na południu Francji wymaga poszerzonych i żmudnych badań ${ }^{2}$. W niektórych wypadkach niepewne są nawet podstawowe dane biograficzne jak data i miejsce urodzenia lub śmierci ${ }^{3}$.

Wzmożenie badań nad twórczością kobiet, jakiego jesteśmy świadkami w ciągu ostatnich lat, pozwala wierzyć, że również sztuka polskich artystek związana z francuskim południem doczeka się odpowiedniego opracowania. Zainteresowanie „,południowymi” dziełami na aukcjach sztuki w Polsce i zagranicą winno być dodatkowym bodźcem dla badań w tej dziedzinie.

U schyłku XIX wieku południe stawało się obszarem, na którym rozgrywały się poszukiwania nowoczesnego języka plastycznego. Obecność awangardy na południu Francji, począwszy od artystycznych podróży Vincenta van Gogha (1853-1890) i Paula Gauguina (1848-1903), poprzez twórczość Paula Cézanne’a (1839-1906), była głównym czynnikiem wpływającym na wybór kierunku artystycznych podróży. Zwłaszcza poszukiwania Cézanne'a prowadzone w l'Estaque w 1870, i następująca po nich wędrówka śladami mistrza z Aix wybitnych reprezentantów francuskiej awangardy, André

\footnotetext{
${ }^{1}$ Por.: E. Bobrowska-Jakubowska, Artyści polscy we Francji w latach 1890-1918. Wspólnoty $i$ indywidualności, Warszawa 2004; taż, „Le milieu des artistes polonais en France 1890-1918, communautés et individualités", praca doktorska pod kierunkiem F. Levaillant, Université Panthéon-Sorbonne, Paris 2001; taż, La présence des artistes polonais en France - état des lieux de la recherche, Ligeia 2009 nr 93-96, s. 67-76; taż, Polska obecność artystyczna we Francji - próba oceny stanu badań, Archiwum Emigracji. Studia - Szkice - Dokumenty 2010 z. 1-2(12-13), s. 175-186; M. Zientara, Artystki polskie i ich sztuka w latach 1900-1939, cz. 2: Przedstawicielki awangardy, Krzysztofory: zeszyty naukowe Muzeum Historycznego Miasta Krakowa 2008 z. 26, s. 201-222; taż, Artystki polskie i ich sztuka w latach 1900-1939, cz. 3: Przedstawicielki koloryzmu, Krzysztofory: zeszyty naukowe Muzeum Historycznego Miasta Krakowa 2009 z. 27, s. 257-290; B. Malinowska, Artyści polscy w Bretanii, [w:] Malarze polscy w Bretanii (1890-1939), [katalog wystawy]. Muzeum Narodowe w Warszawie, Warszawa 2005.

${ }^{2}$ Por.: M. Chrzanowska-Foltzer, „Conversations provençales” — les peintres polonais en France méditerranéenne de 1909 à nos jours. Étude sur les influences et les échanges artistiques, t. 1-3, praca doktorska pod kierunkiem C. Massu, Université de Provence, Aix Marseille I, 2007; taż, „Conversations provençales” - les peintres polonais en France méditerranéenne de 1909 à nos jours, Annales. Centre Scientifique de l'Académie Polonaise des Sciences (Paris) 2008, s. 185-212. Na temat polskiej obecności poza Paryżem w XIX wieku zob.: E. Bobrowska-Jakubowska, Génie créateur face à Genius loci: les artistes polonais et leurs promenades à travers la France au tournant du XIXème siècle, [w:] Genius loci face à la mondialisation [międzynarodowa konferencja], red. Z. Mitosek, A. Ciesielska-Ribard, Paris 2006, s. 97-107 („Les nouveaux cahiers franco-polonais", nr 6).

${ }^{3}$ Do niedawna historycy podawali różne dane biograficzne Niny Aleksandrowicz (Alexandrowicz), istniały wątpliwości, co do miejsca i daty urodzin oraz śmierci artystki. Poprawne daty umieściła w swojej pracy doktorskiej Ewa Bobrowska-Jakubowska; zob.: „Le milieu des artistes polonais en France 1890-1918”, s. 559. Po konsultacji z urzędem stanu cywilnego miasta Pau wątpliwości zostały ostatecznie wyjaśnione; zob.: wypis z księgi Urzędu Stanu Cywilnego w Pau, akt zgonu nr 349 z 7 kwietnia 1945, Nina Alexandrowicz (Stanisławów 1878 - Pau 1945). Grób Niny Aleksandrowicz został uznany za tombe remarquable (grób osoby zasłużonej) i z tego tytułu objęty szczególną ochroną ze strony władz miejskich. Inicjatywie tej towarzyszą badania dotyczące francuskiej kariery tej polskiej malarki.
} 
Deraina, Georgesa Braque'a, Raoula Dufy zrewolucjonizowały koncepcję pejzażu4 . Nowe nurty malarstwa, fowizm, kubizm związały się na stałe z nazwami południowych miejscowości. Do miejsc „,zawładniętych” sztuką, takich jak Cassis, l’Estaque, Aix-en-Provence, Martigues, Collioure, Saint Tropez, lub Céret, kierowali się licznie artyści francuscy a ich wzorem również polscy malarze ${ }^{5}$. Wciąż wzrastająca popularność francuskiego południa osiągnęła apogeum w latach 20. XX wieku. Zwłaszcza niektóre miejscowości, takie jak Saint Tropez, przeżyły najazd kolorowego tłumu turystów i zmagały się ze skutkami ,mody" na południe ${ }^{6}$.

Powstać może mapa tych szczególnie ważnych dla francuskiej sztuki okresu międzywojennego miejsc, ku którym pielgrzymowały także polskie malarki. Warto przypomnieć jak ważną pozycję w sztuce tego okresu zajmowały polskie artystki, które przyjeżdżały z różnych ośrodków artystycznych (Kraków, Warszawa, Łódź, Lwów) do Paryża i kierowały się dalej, ku swoistemu terytorium sztuki, jakim było wówczas południe Francji.

Na początku XX wieku droga na południe prowadziła przez Paryż. I to właśnie dzięki relacjom krytyków z paryskich wystaw, ich sprawozdaniom ilustrowanym z rzadka czarno-białymi fotografiami, a także dzięki notom katalogowym dowiadujemy się o południowych fascynacjach licznych polskich malarek ${ }^{7}$. Jest to materiał niezwykle interesujący pod względem merytorycznym, lecz także, gdy idzie o sposób, w jaki krytyka artystyczna, reprezentowana wówczas niemal wyłącznie przez mężczyzn, opisywała sztukę kobiet i ich spojrzenie na południe. Z analizy owych tekstów wynika, iż krytycy przypisywali sztuce kobiecej pewne cechy stałe jak wrażliwość, świeżość, elegancja, dekoracyjność, barwny egzotyzm. Natomiast odnośnie oceny konstrukcji pejzaży czy techniki rysunku, uznaniem dla talentu artystek było odnalezienie w ich dziełach „męskiej siły” wyrażonej często w „szorstkiej” fakturze, a także wskazanie na obecność pierwiastków „,nowoczesności” i „,stanowczości”.

${ }^{4}$ Historycy sztuki wciąż analizują niezwykle ważny dla nowoczesnego malarstwa okres 1870-1910, od pobytu Cézanne'a po ostatnią podróż Braque'a do l'Estaque. Uznaje się ten przedział czasowy za fundamentalny, gdy idzie o stworzenie nowoczesnego sposobu postrzegania pejzażu, o zróżnicowanie widzenia i wytworzenie nowoczesnych środków plastycznych, od egzaltacji i redukcji koloru u fowistów, do konstrukcji i rozkładu u kubistów; zob.: N. Cendo, V. Serrano, L'Estaque. Naissance du paysage moderne 1870-1910, [exposition] 25 juin-25 septembre 1994, Musée Cantini, Marseille, Marseille 1994; N. Cendo, Une dimension appelée peinture. L'Estaque, 1870-1910, [w:] Sous le soleil. Exactement le Paysage en Provence du classicisme à la modernité (1750-1920), Montréal 2005, s. 183-191; tenże, De l'attrait du bonheur à la recherche de nouvelles voies. Le premier XXe siècle, [w:] Sous le soleil, s. 212-214; P. Conisbee, D. Coutagne, Cézanne en Provence, Paris 2006.

${ }^{5}$ Claude Monet, Auguste Renoir, Vincent Van Gogh, Paul Signac, André Derain, Henri Matisse, Georges Braque, Pierre Bonnard, Pablo Picasso to tylko niektóre nazwiska z długiej listy sławnych, aktywnych we Francji artystów, których twórczość związana była z Południem.

${ }^{6} \mathrm{Z}$ końcem XIX wieku zaczął się zmieniać obraz południowego wybrzeża postrzeganego do tej pory jako „sanatorium Europy”. Podróże na Południe stały się atrakcją nie tylko dla rekonwalescentów szukających w kąpielach słonecznych ratunku dla zdrowia, lecz także dla szerokiego grona turystów, napływających latem i gustujących w ,egzotycznych wyprawach”, popularyzowanych przez ówczesną literaturę i liczne przewodniki.

7 Więcej na ten temat zob.: A. Wierzbicka, Artyści polscy w Paryżu. Antologia tekstów 1900-1939, Warszawa 2008; H. Bartnicka-Górska, J. Szczepińska-Tramer, W poszukiwaniu światta, ksztattu i barw. Artyśsi polscy wystawiajacy na Salonach paryskich w latach 1884 1960, Warszawa 2005.

${ }^{8}$ Por.: A. Basler, Salon Jesienny w Paryżu, Literatura i Sztuka 1909 nr 32, s. 3 (dod. do: Nowa Gazeta nr 546); E. Woroniecki, Les expositions polonaises à Paris (...). Mme Reno chez 
Do pierwszych twórczyń polskich odwiedzających śródziemnomorskie wybrzeże jeszcze przed pierwszą wojną należały Irena Hassenberg (Irène Reno, 1884-1953), tworząca w latach 1910-1911 w tak często odwiedzanym później przez Józefa Pankiewicza miasteczku Sanary, oraz Sonia Lewitska (1874-1937), która związała się z nurtem kubistycznym i w 1912 roku malowała w rozsławionym przez artystów z tego kręgu Céret. Pobyty artystek zaowocowały obrazami wystawionymi na Salonie Niezależnych, Sonia Lewitska wystawiła płótna z Céret w Galerii Berthe Weill w $1913^{9}$.

Zmiany, jakie zaszły po pierwszej wojnie światowej, jeśli chodzi o podmiotowość prawną Polek, spowodowały, że zwiększyła się znacznie liczba podróżujących artystek $^{10}$. W wolnej Polsce kobiety uzyskały prawa obywatelskie a wraz z nimi dostęp do państwowych wyższych uczelni, w tym także plastycznych. Nie musiały już szukać za granicą możliwości profesjonalnego, artystycznego wykształcenia. Uzyskanie osobowości prawnej umożliwiało polskim artystkom podejmowanie decyzji o wyborze artystycznej kariery. Jak słusznie zauważyła Maria Zientara:

mogły, jeśli chciały i miały odwagę, samodzielnie podróżować w celu dokształcenia się lub poszukiwania interesujących motywów ${ }^{11}$.

Udział polskich twórczyń w życiu artystycznym Paryża w latach 20. XX wieku znacznie się zwiększył. Wśród wystawiających na salonach polskich plastyków kobiety stanowiły średnio 30 procent $^{12}$. Znaczna część polskich malarek, uczestniczek salonów, odwiedzała południe. W wielu wypadkach prezentowały swe dzieła pod mało precyzyjnymi tytułami jak ,„pejzaż”, ,pejzaż południowy” lub „miasteczko południowe”, co utrudnia znacznie pracę badawczą ${ }^{13}$.

W okresie międzywojnia, oprócz wymienionych wcześniej artystek, na południu tworzyły: Fryda Frankowska (1872-1957), Mela Muter (1876-1967), Nina Aleksandrowicz (1878-1945), Zofia Piramowicz (1880-1958), Helena Het Kwiatkowska

Druet, La Pologne politique économique, littéraire et artistique 1924 II półrocze, s. 334-335; tenże, Wystawa pani N. Aleksandrowicz (Galerie d'Art Contemporain), Świat 1926 nr 21, s. 3; tenże, L'art polonais à Paris. Exposition de Mme Dora Bianka à la Galerie Manteau, La Pologne politique économique, littéraire et artistique 1928 I półrocze, s. 37; Z. St. Klingsland, Zofia Piramowiczówna, Wiadomości Literackie 1930 nr 26, s. 1.

${ }^{9}$ Zob.: Exposition des peintures, aquarelles, dessins de Mme Lewitzka (Sonia), [préface par Ch. Malpel], du 10 au 27 avril 1913, Galerie de Berthe Weill, Paris 1913.

${ }^{10} \mathrm{Na}$ ziemiach polskich, do 1918 roku obowiązywały konserwatywne kodeksy państw zaborczych: kodeks cywilny Królestwa Polskiego z 1825 roku, kodeks austriacki z 1811 roku i kodeks cywilny niemiecki znowelizowany w 1896 roku. Zdolność prawna kobiet była bardzo ograniczona, restrykcje prawne dotyczyły wszystkich dziedzin życia. Kobiety zamężne uzależnione były od męża, który był ich prawnym przedstawicielem. Najtrudniejszą sytuację pod tym względem miały kobiety w zaborze rosyjskim. Polki, tak jak obywatelki państw zaborczych i innych europejskich państw, były pozbawione praw politycznych. Najbardziej liberalny w tej dziedzinie był obowiązujący w Galicji kodeks austriacki. Czynne i bierne prawo wyborcze Polki otrzymały na mocy dekretu Naczelnika Państwa w listopadzie 1918 roku. Uchwalona 17 marca 1921 roku konstytucja marcowa w artykule 96. zapowiadała równość wobec prawa wszystkich obywateli i tym samym znosiła przepisy ograniczające prawa publiczne kobiet. Odrzucenie przez powołaną w 1919 roku Komisję Kodyfikacyjną konserwatywnych kodeksów państw zaborczych zapewniło Polsce miejsce w czołówce państw demokratycznych.

${ }^{11}$ M. Zientara, Artystki polskie i ich sztuka w latach 1900-1939, cz. 3, s. 289.

${ }^{12}$ Por.: H. Bartnicka-Górska, J. Szczepińska-Tramer, W poszukiwaniu światta.

${ }^{13}$ Należy pamiętać, że pod takim tytułem mogły się kryć nie tylko dzieła prowansalskie, lecz także płótna powstałe podczas modnych w latach 20. podróży do Hiszpanii, a gdy idzie o drugą połowę lat 30., również do Włoch. 
(1882-1956), Zofia Schomberg-Szymberska (1883-1943), Alicja Halicka (18941975), Dorota Kucembianka (Dora Bianka, 1895-1979) ${ }^{14}$, Sonia Bornstein (19071944). Artystki te rozwijały kariery w Paryżu, ich artystyczne losy na zawsze związały się z Francją. Niektóre z wyżej wymienionych twórczyń powracały regularnie do ulubionych miejsc na południu Francji lub wręcz osiedlały się tam na stałe ${ }^{15}$. Plon owych podróży artystycznych jest dziś przynajmniej częściowo znany.

Mela Muter od 1921 roku, czyli od pierwszego pobytu w Saint Tropez i w Trayas, regularnie malowała w świetle południa. W latach 1921-1926 jeździła do modnego wówczas Collioure. Pejzaże Meli Muter z okolic Collioure to chyba jedne z najbardziej znanych obecnie, ,południowych" dzieł polskich artystek. Do Collioure, rozpowszechnionego przez fowizm, podróżowały w latach 20. także Nina Aleksandrowicz, Het Kwiatkowska oraz należące do grupy kapistów Hanna Rudzka-Cybis (1897-1988) i Dorota Berlinerblau Seydenman (1902-1944). Zofia Schomberg-Szymberska pracowała tam w latach 1935-1937, odwiedzała też Saint Tropez i Korsykę. Port w Marsylii inspirował wiele artystek, w okresie największej popularności południa, przypadającym na lata 1925-1928, malowały tam między innymi Dora Bianka i Sonia Bornstein. Osławione przez Renoira, a później także przez Soutine'a, Cagnes odwiedzali licznie polscy malarze, choćby Zygmunt Waliszewski czy Tytus Czyżewski, a spośród malarek Irena Hassenberg. W latach 30. artystka malowała w Vence, miasteczku wcześniej odwiedzanym przez Sonię Lewitską, pozostającą w okresie 1921-1924 w kręgu sztuki Raoula Dufy ${ }^{16}$.

Dla niektórych artystek południe było jednym z etapów dalszych podróży, na Korsykę, ku północnym wybrzeżom Afryki lub do Hiszpanii ${ }^{17}$. Pochodząca z lwowskiego środowiska artystycznego, przedwcześnie zmarła malarka i ilustratorka Anna Harland-Zajączkowska (1883-1930), podróżowała po wybrzeżach Adriatyku w poszukiwaniu interesujących motywów architektonicznych. Zawdzięczamy jej oddające lokalny, ciepły koloryt widoki Carcassonne z 1926 roku (il. 40), podejmowane w późniejszych latach w stylistyce operującej uproszczonymi, stylizowanymi płaszczyznami i żywą, gładko kładzioną barwą.

${ }^{14}$ Bureau d'Etat Civil Le Chesnay, wg aktu zgonu, rejestr nr 160 z 18.09.1979 — Dora Bianka (1896-1979).

${ }^{15}$ Nina Aleksandrowicz związana była z krajem Basków, zmarła w Pau w 1945. Fryda Frankowska w 1930 roku osiedliła się w leżącym obok Aix en Provence Orcel (dzisiaj należące do aglomeracji miejskiej Aix en Provence). Het Kwiatkowska od 1935 roku zamieszkiwała w Chateauneuf de Grasse.

${ }^{16}$ Zob.: Sonia Lewitzka, Peintures et aquarelles, préf. Ch. Vignier, [katalog wystawy]. Paris, Galerie Berthe Weill, 10-23 listopada 1924, Paris 1924. Obraz z tego okresu znajduje się w kolekcji Musée Mainssieux we Voiron; zob.: Sonia Lewitzka, Paysage de Vence, ok. 19211924, olej, płótno, $46 \times 56$, Musée Mainssieux, Voiron.

${ }^{17}$ Artystki polskie chętnie podróżowały, o czym świadczą niektóre niezwykle bogate życiorysy. Posiadały często oparcie w rodzinie lub odbywały podróże u boku męża. Znajdowały także zatrudnienie, np. jako nauczycielki rysunku. Mela Muter przebywała w Collioure z Amerykanką panną Scoffield, której udzielała lekcji malarstwa. Znaną ze swych licznych podróży była Zofia Piramowicz, która oprócz południowej Francji, w okresie międzywojnia odwiedzała także Włochy, Hiszpanię, Algier, Tunezję i Maroko. Podarowała niezwykle cenne zbiory sztuki marokańskiej Muzeum Etnograficznemu w Krakowie. Zespół jej prac z podróży do północnej Afryki znajduje się w zbiorach Biblioteki Polskiej w Paryżu. Irena Hassenberg malowała na Sycylii, na Korsyce a w 1925 roku odbyła podróż do Stanów Zjednoczonych i Meksyku. Dora Bianka odbywała dalekie podróże m.in. do Australii, Południowej Afryki, na Cejlon, do Egiptu, Algieru i Hiszpanii. 
Znamy niewielką część prowansalskiego dorobku polskich artystek ${ }^{18}$. Istnieje natomiast spory zbiór zdjęć, pism, korespondencji, który pozwala odtworzyć klimat podróży i dopełnia wizję południa stworzoną przez polskie artystki. To właśnie artystkom zawdzięczamy opisy miejsc i południowych wędrówek. Wystarczy wspomnieć pisma Meli Muter, a zwłaszcza jej poetyckie opisy portów Collioure czy Saint Tropez. Równie ciekawą lekturą są Souvenirs (Wspomnienia) Alicji Halickiej zawierające opis Ste Maxime i St Tropez z 1924 roku ${ }^{19}$. Z listów Hanny Rudzkiej-Cybisowej do matki, a także do brata, dowiadujemy się o dokładnym przebiegu wyprawy kapistów na południe Francji latem 1925 roku. Kolejne, słane do Polski karty dokumentowały podróż, opisywały klimat i pejzaże. Wskazywały na zachwyt i entuzjazm pracujących na wybrzeżu artystów. Niekiedy informowały o stanie ducha skonfrontowanych ze śródziemnomorskim pejzażem młodych artystów. Kobiety utrzymywały więzi z krajem, z bliskimi. Lubiły także fotografie. Wycieczka kapistów po francuskim południowym wybrzeżu, od Mentony do La Ciotat, jest jedną z lepiej udokumentowanych eskapad południowych polskich artystów, a to dzięki aparatowi fotograficznemu Doroty Berlinerblau. Na jednym ze zdjęć ze zbiorów Muzeum Historycznego Miasta Krakowa widzimy ją w La Ciotat, gdy wyrusza na plener ze sztalugami, zaopatrzona w kapelusz $\mathrm{z}$ dużym rondem, nieodzowny atrybut każdego artysty ryzykującego studiowanie letniego, południowego pejzażu. To także Dorocie Berlinerblau zawdzięczamy fotograficzne pamiątki z pobytu Jana Cybisa i Hanny Rudzkiej-Cybisowej w Collioure latem 1926 roku $^{20}$. Kobiety artystki często fotografowały się podczas pracy na śródziemnomorskim wybrzeżu. Rozstawienie sztalug wśród południowego krajobrazu było z pewnością powodem do dumy. Tak właśnie postrzegamy Melę Muter na zdjęciu z Collioure z $1925 \mathrm{roku}^{21}$. Ta i podobne jej fotografie były czymś więcej niż tylko pamiątką ze studiów pejzażowych odbywanych w egzotycznych miejscach, stanowiły także ważny dokument zmian kulturowych. Dostęp kobiet do praktyki plenerowej był przecież jakże istotnym etapem w rozwoju sztuki początku XX wieku.

Czego poszukiwały kobiety malarki na południu - czy pięknych widoków, idyllicznych pejzaży, których dostarczało im śródziemnomorskie wybrzeże? Fascynacja południem przeradzała się w głęboko odczuwaną wizję. Świadomość zadań malarskich stanowiła wyzwanie dla artystek dążących ku nowoczesnej wizji plastycznej. Kryterium autentyczności własnej sztuki, wypływające z indywidualnego doświadczenia, było istotne w ich spotkaniu ze śródziemnomorskim krajobrazem. Kadrowany według zasad nowoczesnej perspektywy, stylizowany, czasem traktowany wręcz dekoracyjnie motyw pejzażowy trafiał na płótna artystek z różnych nurtów stylistycznych. Malowały pejzaże, motywy architektoniczne, uliczki, miasteczka osadzone wśród wzgórz i ota-

\footnotetext{
${ }^{18}$ Dorobek został rozproszony, uległ zniszczeniu lub trafił do prywatnych kolekcjonerów, co utrudnia prowadzenie badań. Nie zawsze udaje się odnaleźć dzieła, które zgodnie ze wskazówkami źródłowymi, powinny znajdować się we francuskich zbiorach muzealnych.

${ }^{19}$ A. Halicka, Hier. (Souvenirs), Paris 1946; wyd. polskie: Wczoraj: wspomnienia, autoryzowany przkł. W. Błońska, Kraków 1971.

${ }^{20}$ Zob.: M. Chrzanowska-Foltzer, Odkrywanie krajobrazów południowej Francji-podróże kapistów w świetle badań, dokumentów i fotografii, Krzysztofory: zeszyty naukowe Muzeum Historycznego Miasta Krakowa 2009 z. 27, s. 291-306.

${ }^{21}$ Fot. reprodukowana w: B. Nawrocki, Mela Muter, jej malarstwo, jej modele, [w:] Mela Muter: (Maria Melania Mutermilch 1876-1967): Kolekcja Bolestawa i Liny Nawrockich, [katalog wystawy]. Muzeum Narodowe w Warszawie, grudzień 1994-luty 1995, [oprac. B. Brus-Malinowska, B. Nawrocki; oprac. red. E. Zdonkiewicz], Warszawa 1994, s. 36; fot. obecnie w zbiorach Archiwum Emigracji w Toruniu.
} 
czającą je południową roślinność. Port był często powracającym motywem, traktowanym jako istotne wyzwanie kompozycyjne ze względu na organizację przestrzeni, zrytmizowanej liniami konstrukcji, masztów, żagli, i na kontrast między owym rygorem a giętkością, przypadkowością form stworzonych przez naturę. Zainteresowanie naszych artystek wzbudzały także „typy prowansalskie” czy „typy z Katalonii”, kobiety w czarnych sukniach, pasiastych chustach, ujmowane portretowo czy przedstawiane w scenach macierzyństwa ${ }^{22}$. Poziom południowych prac naszych artystek z tego okresu nie jest jednolity. Spośród wymienionych już wcześniej twórczyń wiele zostało zapomnianych, w większym lub mniejszym stopniu. Jedynie Melę Muter zaliczyć można do dostatecznie docenionych i lepiej poznanych artystek polskich. Jej twórczość doczekała się wielu opracowań i stanowi wciąż obiekt zainteresowania badaczy. To w dużej mierze dzięki jej płótnom francuskie południe zapisało się na kartach polskiej historii sztuki. Mela Muter malowała porty w Saint Tropez, Collioure, Marsylii czy La Ciotat. W drugiej połowie lat 30. związała się ze środowiskiem artystów w Awinionie. Była członkinią związków zrzeszających lokalnych malarzy i brała czynny udział w grupowych wystawach. Zasłynęła w latach 20. w Paryżu jako portrecistka przedstawicieli sztuki i polityki. Przebywając w Awinionie, już w okresie drugiej wojny, znajdowała modele wśród populacji cygańskiej zamieszkującej u nabrzeży Rodanu. Te same twarze w różnych ujęciach pojawiają się na płótnach malowanych w okolicach wyspy Barthelasse, niedaleko Quais de la Ligne, gdzie zamieszkiwała artystka. Istnieje seria portretów o niemal religijnym charakterze i o niezwykłej sile wyrazu ${ }^{23}$. Stare kobiety o twarzach mocno rzeźbionych przez czas ujęte są monumentalnie na tle architektury, a często rzeki i skał. Te dwa ostatnie elementy plastycznej konstrukcji płótna nabierają także znaczenia symbolicznego — woda, jako element oznaczający upływ czasu i skała, jako opór materii wobec czasu. Portretowane kobiety trwają w pozie cichej kontemplacji. Sądzić można, że istnieje swoista więź między portretowanymi kobietami, stawiającymi opór trudom życia i artystką prowadzącą codzienną walkę o prawdziwy, ponadczasowy wymiar swej sztuki.

W autoportrecie z mandoliną Mela Muter przedstawiła się na płynącej po wzburzonym Rodanie barce ${ }^{24}$. Zasłuchana w głos własnej sztuki zdaje się być nieczuła na unoszący ją nurt rzeki. Mandolina, atrybut sztuki, pozwala na skojarzenia ikonograficzne nawiązujące do prowansalskiej kultury. „Typy Prowansalek” popularyzowane przez tanie wydawnictwa i kartki pocztowe z początku XX wieku to często Arlezjanki przedstawione właśnie $\mathrm{z}$ mandoliną 25 .

W okresie drugiej wojny światowej losy kobiet artystek ze względów politycznych związały się z południem Francji. Utworzona po 22 czerwca 1940 roku strefa nieokupowana zwana wolną strefą, obejmowała południe Francji i dawała lepsze warunki do

${ }^{22}$ Obrazy takie znajdziemy głównie w dorobku Niny Aleksandrowicz; por.: Nina Aleksandrowicz, Stara Prowansalka, 1923, olej, płótno, $90 \times 70,5$ cm, MPW 184483, Muzeum Narodowe, Warszawa (il. 39).

${ }^{23}$ Por.: Mela Muter, Femme priant. Kobieta modlaca się, ok. 1940, olej, płótno, $81 \times 63 \mathrm{~cm}$, dawna kolekcja Masquin, Awinion; Mela Muter, La Solitude. Samotność, ok. 1940, olej, płótno, $80 \times 65 \mathrm{~cm}$, dawna kolekcja E. i W. Fibaków, obecnie na rynku antykwarycznym.

${ }^{24}$ Mela Muter, Autoportret z mandolina, ok. 1940, olej, płótno, obraz z kolekcji B. i L. Nawrockich; reprodukcja w: Mela Muter. Malarstwo / Peinture, [katalog zbiorów, red. M. A. Supruniuk, S. Majoch], Toruń 2010, s. 157.

${ }^{25}$ Trudno tu nie doszukiwać się także dalekich reminiscencji średniowiecznej kultury prowansalskiej, która sprzyjała sztuce kobiet poetek. Spośród znanych we Francji autorek poezji i pieśni (cansos) z XII i XIII wieku duża część zamieszkiwała na Południu. 
przetrwania. Przynajmniej do listopada 1942 czyli do inwazji włoskiej, południe stało się schronieniem dla uchodźców z Paryża. Sytuacja pogorszyła się, gdy wojska włoskie zostały zastąpione siłami Wehrmachtu. Znaczna część uciekinierów kierowała się na Lazurowe Wybrzeże, a także do Marsylii, z której organizowano przerzut ukrywających się osób, via Portugalia, do Stanów Zjednoczonych lub do Brazyliii ${ }^{26}$. Duża grupa artystów polskich ukrywała się przez lata wojny w południowych regionach Francji. Kontakty nawiązywane przed wojną ułatwiały znalezienie bezpiecznego miejsca. Wspomniana wyżej Mela Muter zamieszkiwała w okolicach Awinionu, w Villeneuve, potem w samym Awinionie. Pomimo materialnych trudności dużo tworzyła, głównie pejzaże z okolic Villeneuve, malowała fort Saint André, a także widoki na Awinion i nabrzeża Rodanu. Zacieśniła kontakty ze środowiskiem artystycznym — w 1945 roku uczestniczyła w grupowej wystawie malarzy awiniońskich ${ }^{27}$.

Istotnym ośrodkiem było oddalone o $35 \mathrm{~km}$ od Marsylii Aix en Provence. W maju 1940 roku Jan Wacław Zawadowski, uczeń Pankiewicza przeniósł z Paryża do Orcel koło Aix en Provence filię krakowskiej akademii. Żywot filii był krótki, czasy wojenne uniemożliwiały funkcjonowanie takiej struktury. Orcel i pracownia Zawadowskiego pełniły jednak nieoficjalnie funkcję polskiego ośrodka kultury i oporu wobec okupanta. W Orcel znaleźli schronienie studenci paryskiej filii Kazimierz Zielenkiewicz i jego żona Lutka Czajndla Pinkusiewicz (1906-1999) zwana Lutką Pink. O ile o działalności Zielenkiewicza (Caziela) z tego okresu wiadomo dość dużo, aktywność artystyczna Lutki Pink jest mniej znana. Zachował się portret artystki wykonany w latach 40. przez profesora Zawadowskiego ${ }^{28}$. Z okresu wspólnej z Cazielem pracy nad motywem pejzażowym pozostało niewiele dzieł. Świadczą one o badaniu walorów syntetycznych koloru oraz o powolnym odchodzeniu od motywu ku abstrakcji ${ }^{29}$. Kolonia artystów uchodźców w Aix en Provence stanowiła środowisko aktywne. W okresie wojny przebywali tu m.in. Francis Tailleux, Pierre Tal-Coat, z którymi polscy twórcy utrzymywali stałe kontakty. W marcu 1945 artyści przedstawili swój dorobek na wystawie zorganizowanej przez Cercle Universitaire Interallié ${ }^{30}$.

${ }^{26}$ Zaangażowanie osiadłych na śródziemnomorskim wybrzeżu intelektualistów w działalność antynazistowską i w pomoc ukrywającym się artystom jest zjawiskiem znanym. Zwłaszcza aktywność amerykańskiego dziennikarza Variana Fry, który uratował tysiące działaczy antynazistowskich, w tym pisarzy i artystów, doczekała się licznych opracowań. Znane jest także zaangażowanie hrabiny Lily Pastré — w jej posiadłości Campagne Pastré w Marsylii znajdowali schronienie znani malarze i muzycy.

${ }^{27}$ Zob.: Première Exposition de la Société Nouvelle des Peintres Indépendants. Hôtel de Ville, Awinion, od 31 marca do 15 kwietnia 1945; Mela Muter nr kat. 66-71. W czasie wojny artystka wystawiała z grupą artystów ukrywających się w Prowansji. Cavaillon od 8 do 20 sierpnia 1941; Mela Muter nr 468-473.

${ }^{28}$ Jan Wacław Zawadowski, Portret Lutki Pink, olej, płótno, $100 \times 73 \mathrm{~cm}$, na rynku antykwarycznym, aukcja Agra-Art, Warszawa, 23 marca 2009, nr kat. 84.

${ }^{29}$ Por.: Lutka Pink, Paysage estival du Midi (Letni pejzaż potudniowy), ok. 1940, olej, płótno, $38 \times 46$. Aukcja Ecole de Paris. Pologne, Russie, Europe Centrale. Dom Aukcyjny Boisgirard, ekspert Krzysztof Zagrodzki Paryż, Drouot-Richelieu, 26 marca 2008 (nr kat. 110).

${ }^{30} \mathrm{Na}$ zaproszeniu widnieją nazwiska dziesięciu wystawiających: Marcel Arnaud, Paul Clement, Jacques d'Otemar, Greta Knutson, Jean-Marie Loustaunau, André Marchand, Léo Marschutz, Lutka Pink, Pierre Tal- Coat, Casimir Zielenkiewicz. Wystawa od 15 do 30 marca 1945, archiwum Zielenkiewicza w Isle Brewers; zob.: D. Monkiewicz, Caziel. Kazimierz Józef Zielenkiewicz 1906-1988, [katalog wystawy]. Muzeum Narodowe w Warszawie, 3 sierpnia - 27 września 1998, Warszawa 1998, s. 38. 
W Aix en Provence mieszkała i wystawiała w czasie wojny także Dora Bianka, zdobywając uznanie krytyki i pochlebne artykuły w lokalnej prasie. Po paryskich i londyńskich sukcesach, polska malarka przedstawiana była jako wyjątkowa i wyrafinowana osobowość, władająca perfekcyjnie techniką akwareli i gwaszu ${ }^{31}$. Jej prowansalski dorobek stanowiły widoki z Mas Provençal, w którym zamieszkiwała, pejzaże z drzewami oliwnymi, kwitnącymi migdałowcami malowane techniką olejną ${ }^{32}$. Najliczniejsze z tego okresu są gwasze, w tym widoki portu w Marsylii. Twórczość Dory Bianki jest w Polsce prawie nieznana a we Francji zapomniana. Pojawiające się z rzadka na rynku antykwarycznym dzieła są jedyną okazją do przypomnienia tej interesującej malarki ${ }^{33}$.

Sytuacja polityczna zaistniała po drugiej wojnie światowej spowodowała długotrwały dualizm w kulturze polskiej i rozdział pomiędzy twórcami, którzy wyemigrowali z kraju po 1945 lub wybrali pozostanie na emigracji w wypadku, gdy działania wojenne zastały ich poza granicami Polski a artystami pozostałymi w kraju. Kariery żyjących na południu polskich twórców, rozwijały się w znacznie trudniejszych warunkach w porównaniu do środowiska paryskich kolegów ${ }^{34}$. W przypadku artystek sytuacja była jeszcze bardziej złożona. Trudności finansowe, brak możliwości wystawienniczych, utrata kontaktów z rodziną i z krajem rzutowały na pozycję polskich malarek we francuskim środowisku artystycznym. Jednostki, którym udało się utrzymać wysoką pozycję w świecie sztuki to wybitne indywidualności artystyczne. Do nich z pewnością należała Mela Muter, której powojenna działalność rozwijała się w Paryżu, a także w Awinionie, gdzie do 1964 roku miała swoją pracownię. Natomiast dorobek mieszkającej na stałe w okolicach Grasse (Chateauneuf de Grasse, departament Alpes Maritimes) Heleny Het Kwiatkowskiej został zupełnie zapomniany. Prowadzone przeze mnie badania nad twórczością Kwiatkowskiej pozwoliły ustalić jej powojenne losy i zlokalizować zbiór ponad trzydziestu dzieł, znajdujący się w kolekcjach prywatnych we Francji i w Stanach Zjednoczonych. Są to głównie martwe natury, akty kobiet (il. 41), a także pejzaże z Le Mas Vieux, pięknej XVIII-wiecznej, południowej posiadłości, w której malarka zamieszkiwała przez ponad dwadzieścia lat ${ }^{35}$.

Mało znane są również prace Eleonory Reinhold (1905-1984), która w latach 50. wraz z mężem Janem Ekiertem, malarzem z kręgu abstrakcjonistów, odwiedzała wielokrotnie południe Francji, okolice Nîmes, Saint Rémy de Provence czy Saint Agnès

${ }^{31}$ Wystawa Dory Bianki, Galerie de Provence, Aix en Provence, Cours Mirabeau, styczeń 1941; zob.: Dora Bianka, Mémorial d'Aix 12.01.1941, s. 1; L'Exposition de Mme Dora Bianka, Mémorial d'Aix 19.01.1941, s. 1.

${ }^{32}$ Do tej pory nieznany był prawie zupełnie okres twórczości artystki w Aix en Provence. Z ostatnich moich badań wynika, iż artystka zamieszkiwała przez cały okres drugiej wojny w Aix en Provence, w dzielnicy Saint Mître, niedaleko posiadłości Zawadowskiego. Nie udało się ustalić czy miała kontakty z innymi polskimi artystami osiadłymi w Aix. Pewne stylistyczne cechy płócien Dory Bianki z tego okresu wskazują, że mogła kontaktować się z Zawadowskim lub przynajmniej znała jego twórczość.

${ }^{33}$ Por.: Wystawa ok. czterdziestu prac polskich artystek XIX i XX wieku, „Damy polskiej sztuki”, Salon Wystawowy Marszand, Warszawa, 8 marca - 4 kwietnia 2010, nr 11: Dora Kucembianka, Pejzaż w btękicie, olej, płótno 37,2 × 55,2 cm; nr 12: Dora Kucembianka, Souvenir de Palma olej, płótno 55,5 × 33,5 cm. Wystawiono także pejzaż Lutki Pink z lat 50 (nr kat. 39).

${ }^{34}$ W Paryżu działał powstały w 1956 roku Związek Artystów Polskich we Francji. Związek wydawał „Biuletyn”, w którym umieszczano informacje o karierach osiadłych na południu polskich malarzy, w tym także artystek.

${ }^{35}$ Notatka po śmierci Heleny Kwiatkowskiej; zob.: Szkice biograficzne zmartych kolegów, Biuletyn Związku Artystów Polskich we Francji (Paryż) czerwiec 1959, s. 17. 
(Alpes Maritimes) $^{36}$. Oboje studiowali w paryskiej Académie André Lhote. Liczne wspólne podróże po Europie, w tym także na południe Francji i dalej jeszcze na Majorkę, Sycylię, Korsykę, do Tunezji, Maroka i Egiptu rozwijały ich malarską wizję. Południowe płótna Eleonory Reinhold to widoki krajobrazowe świadczące o poszukiwaniach w zakresie formy i koloru. Mocno wyrażona, niemal architektoniczna struktura pejzaży współgra z harmonijnie rozłożonymi plamami barwnymi (il. 43). Można sądzić, że owe studia prowansalskie były istotnym etapem na drodze ku abstrakcyjnej sztuce. Kolor pozostawał nośnikiem pierwotnej inspiracji czerpanej z wnikliwych studiów natury. Była to droga, jaką kroczyło wielu malarzy abstrakcjonistów.

Artystką, której należy poświęcić więcej uwagi jest Maria Sperling (1898-1995). Jej losy ułożyły się inaczej od życiorysów innych polskich artystek działających we Francji. Zaczęła bowiem karierę na południu, w Nicei, by ją zakończyć w Paryżu. Niewiele wiadomo o przedwojennej działalności Marii Sperling. Gdy przyjechała do Nicei po 1921 roku, wraz z mężem architektem, posiadała już profesjonalne wykształcenie zdobyte w krakowskiej akademii, w klasie swego szwagra Wojciecha Weissa. Willa Joyeuse, w której Maria Sperling mieszkała wraz mężem, a od 1949 roku już jako wdowa, była wspaniale położona.

Był to stary mas - wspominała artystka - najstarszy dom w dzielnicy, który mój mąż unowocześnił. Mieliśmy niesamowity widok na Cap d'Antibes, na Saint-Jeannet, na port w Nicei. [...] mieliśmy spory gaj oliwny i drzewa owocowe [...] to był prawdziwy raj ${ }^{37}$.

Wojciech Weiss i jego żona Irena Weiss (Aneri), również malarka, bywali w okresie międzywojennym częstymi gośćmi owego raju w Nicei. Oprócz walorów widokowych cenne dla artystów było także sąsiedztwo. Jeszcze przed wojną Maria Sperling odwiedzała Matisse'a, a po wojnie, gdy zamieszkał w dzielnicy Cimiez, składała mu wizyty kilkakrotnie. Podziwiała jego kolekcję, obrazy Picassa, Marqueta, odkrywała, wyjątkowy, intymny świat Matisse'a, wolierę z ptakami oraz „dywany pochodzące z Maroka, które służyły za tło do obrazów".

Ostatni raz, gdy u niego byłam pracował nad dużymi kolażami i nad kaplicą w Vence. Od progu widać było zawieszone na ścianach projekty ornatów do tej kaplicy, której poświęcał końcowe lata życia ${ }^{38}$.

Artystka podziwiała Matisse'a, jako największego kolorystę swych czasów, posiadającego, jak twierdziła, wyczucie koloru porównywalne do słuchu absolutnego u muzyków, tak że nigdy się nie mylił ${ }^{39}$. Spotkania z Matissem inspirowały z pewnością Marię Sperling do prowadzenia poszukiwań w technice kolażu. Zaczęła wprawdzie karierę wystawienniczą od malarstwa figuratywnego, dwie pierwsze wystawy indywidualne prezentowały twórczość należącą do nurtu postimpresjonistycznego, lecz już w drugiej połowie lat 40. pojawiły się jej pierwsze kolaże, niezrywające jeszcze całkowicie

${ }^{36}$ Spuścizna Eleonory Reinhold (około 400 prac), znajduje się w Bibliotece Polskiej w Paryżu; zob.: A. Czarnocka, M. M. Grąbczewska, Artyści polscy w Paryżu: zbiory artystyczne Biblioteki Polskiej w Paryżu, Gdańsk 2010, s. 114-117.

${ }^{37}$ Fragmenty wywiadu z Marią Sperling przeprowadzonego przez Jacquesa Chancela i emitowanego w radiu France Inter 27 kwietnia 1979 roku (la Radioscopie de Jacques Chancel avec Marie Sperling); wywiad opublikowany w: J. Selz, Marie Sperling. Encres et Collages, New York 1985, s. 29 [tłum. M. Chrzanowska-Foltzer].

${ }^{38}$ Tamże, s. 21-23.

${ }^{39} \mathrm{Nie}$ bez powodu używała muzycznych odniesień, zanim rozpoczęła studia plastyczne była uczennicą krakowskiego konserwatorium, w klasie fortepianu profesora Eisenberga. 
z figuracją jak Karnawat $w$ Nicei $^{40}$. Kontakty z awangardowym środowiskiem artystycznym, z twórcami takimi jak Jacques Villon, Jean Arp czy Alberto Magnelli, utwierdzały ją w poszukiwaniach nowych dróg twórczych. Spotkanie z Józefem Jaremą (1900-1974) w Rzymie w 1950 roku przypomniało lata studiów w krakowskiej akademii. Zrodzona między artystami więź, rozwijała się na kartach korespondencji, która stanowi świadectwo pasji twórczej, jaką oboje byli zajęci i którą postanowili wnieść we wspólne życie ${ }^{41}$. Jarema zamieszkał z Marią Sperling w willi Joyeuse, w nicejskiej dzielnicy La Lanterne pod koniec 1951 roku. Był to początek wspólnego życia wypełnionego twórczym zapałem, wciąż nowymi wyzwaniami. Duet artystyczny z Józefem Jaremą stanowił przykład harmonijnej współpracy i współbrzmienia talentów obojga artystów. Malarstwo Marii Sperling ewoluowało ku abstrakcji, zapewne także dzięki wpływom Jaremy. Malarz doceniał, jak można sądzić z listów, figuratywną sztukę Marii Sperling, lecz pragnął przekonać artystkę, ,że sztuka abstrakcyjna nie jest tylko nową szkołą, ale nową koncepcją formy, nową estetyką [...]"42. Jego idee padały na podatny grunt. Maria Sperling była artystką dojrzałą i świadomą celów swej sztuki. Nigdy nie zatraciła własnej drogi a współpraca z Jaremą rozwijała jej wizję. Szkoda, więc, że dziś bardziej pamięta się nazwisko Jaremy a twórczość Marii Sperling jest nieco zapomniana. Oboje byli niezwykle aktywnymi organizatorami życia kulturalnego. Założyli, zrodzony z inicjatywy Jaremy i działający pod jego kierownictwem Art Club w Nicei, z Matissem i Picassem jako członkami Komitetu Honorowego. W 1963 roku zorganizowali także pierwszy Festival des Arts Plastiques de la Côte d'Azur (Festiwal Sztuk Plastycznych Lazurowego Wybrzeża - Antibes, Cannes, Monaco, Nicea) z udziałem krytyka Jacques Lepage’a oraz rzeźbiarzy i malarzy jak J. Villeri, P. Faniest, A. Hayart, N. Sufren-Reymond ${ }^{43}$.

Idea poszukiwań w zakresie materii malarskiej przyświecała Jaremie i Marii Sperling przez cały okres ich wspólnej, nicejskiej kariery. Nowa dynamika malarstwa Jaremy jawiła się, jak sam określał w „transmutacji materii, farby w kolor”. Wykonywał reliefy, kolaże, używając nowych eksperymentalnych materiałów i technik, zgodnie z zasadą bezpośredniego doświadczenia (expérience directe). Maria Sperling również zajmowała się materią, uprawiała mozaikę, tkaninę czy kolaż, pracowała także w meta$\mathrm{lu}^{44}$. Artystka w ten sposób tłumaczyła głęboki wymiar swych poszukiwań:

Dzięki zabiegowi, który polega na wprowadzeniu porządku w nieład bezkształtnych elementów, na obudzeniu ducha minerału, wełny, kolorowej masy, i który prowadzi do uzyskania żywej substancji, staram się stworzyć wydajną, mocną więź między światem wewnętrznym a światem zewnętrznym ${ }^{45}$.

Szczególnie upodobała sobie techniki na papierze, stwarzając zupełnie nowy proceder zastosowania tuszu litograficznego, nie do odbitek, lecz kładzionego bezpośrednio na

${ }^{40}$ Wystawy indywidualne Marii Sperling miały miejsce w Nicei, w Galerie Gaffié (1945) i w Galerie Muratore (1946). Maria Sperling, Carnaval à Nice / Karnawat w Nicei, 1946, kolaż, $43 \times 35 \mathrm{~cm}$, kol. prywatna.

${ }^{41}$ Zachowały się jedynie listy Jaremy do Marii Sperling. Artystka swoją część spaliła, uznając ją za mniej ważną.

${ }_{42}$ List Jaremy do Marii Sperling, Rzym 15 października 1950; zob.: J. Jarema, Listy do Marii Sperling 1950-1974, oprac. W. Banach, Sanok 2000, s. 23.

${ }^{43}$ Festiwal odbywał się do 1966 roku. Jarema zapraszał do udziału w nim m.in. artystów włoskich, z którymi utrzymywał kontakty podczas częstych pobytów w Rzymie.

${ }^{44}$ W 1958 roku wykonała trzy mozaiki dla lotniska w Nicei.

${ }^{45}$ Wypowiedź Marii Sperling; J. Selz, Marie Sperling, s. 9. 
podłoże. Uzyskiwała tym samym interesujące efekty głębi i zróżnicowania tonów (il. 42). Studia nad kolorem, dążenie do uzyskania odpowiedniej ,jakości koloru”, dialog między formą a barwą, czyli odpowiednie komponowanie płótna tak, aby uzyskać harmonię między strukturą a pożądanym brzmieniem, stanowiły, obok poszukiwań w dziedzinie materii malarskiej, główną oś jej sztuki. Można zastanawiać się nad tym, czy i w jakim stopniu jej szczególna wrażliwość na kolor rzutowała na poszukiwania twórcze Jaremy.

W 1955 wspólnie z Jaremą założyli w willi Joyeuse, warsztat tkacki, w którym powstawały gobeliny według ich własnych projektów, lecz także według projektów znanych artystów takich jak Arp, Bloc, Magnelli, Villon. Stosowanie materii szorstkiej i prymitywnej, to znów gładkiej i miękkiej pozwalało na zróżnicowanie splotów, niuansowanie abstrakcyjnych kompozycji, które nabierały walorów „,poezji przestrzennej"46. Kariera Marii Sperling rozwijała się głównie na Lazurowym Wybrzeżu, lecz dzieła jej podróżowały na międzynarodowe wystawy. Niestety za życia artystki tylko dwa razy wystawiane były w Polsce, w 1960 (objazdowa wystawa tkanin) i w 1969 w Warszawie i Krakowie. Kontakty z Polską utrzymywała głównie dzięki więzom rodzinnym. Wnuk Marii Sperling zapamiętał atmosferę, w jakiej wspólnie z Jaremą żyli i tworzyli:

Polskość, poprzez swoje sprzeczności i swoją otwartość na ciekawy i różnorodny świat, bez wątpienia była w nich głęboko zakorzeniona. [...] Sztuka wytwarzania wokół siebie atmosfery spokojnej przystani po to, aby przekładać swoje myśli na język barw, kształtów, materiii ${ }^{47}$.

Owa atmosfera przyciągała artystów. Willa Joyeuse stała się nieformalnym centrum kultury i sztuki, miejscem spotkań wielonarodowościowego kręgu przyjaciół artystów z Francji, Włoch, Niemiec, Szwajcarii, a także z Polski.

Wyjątkowymi gośćmi w tym pełnym emulacji artystycznych miejscu bywali Witold Gombrowicz i Rita Labrosse, mieszkający w pobliskim Vence od 1964 roku.

Gombrowicz kultywował szczególny rodzaj pogardy dla malarstwa a zwłaszcza dla malarzy ${ }^{48}$. Paradoksalnie jednak, od przyjazdu do Vence, Gombrowicz otaczał się prawie wyłącznie artystami ${ }^{49}$. Maria Sperling należała do grona kilku cenionych przez niego malarek. Jej dzieła trafiły do ruchomej kolekcji obrazów, jaką stworzył Gombrowicz w willi Alexandrine ${ }^{50}$. Pisarz sam komponował ekspozycję w zależności od

${ }^{46}$ Jedna z pierwszych wystaw tkanin Jaremy, Marii Sperling i André Bloca miała miejsce w Galerie M.A.I. w Paryżu w marcu 1957 roku.

${ }^{47}$ Ch. Leprette, Świat kolorów, [w:] Sonorité visuelle: Maria Jaremianka, Witold Gombrowicz, Józef Jarema, [katalog wystawy], Kraków 2004, s. 45.

${ }^{48}$ Prowokacyjne deklaracje pojawiały się regularnie na kartach „Dziennika”, gdy tylko mówił o wydarzeniach ze świata plastyki. W wypowiedziach o sztuce przeciwstawiał dynamikę słowa inercji, jaką odznaczała się jego zdaniem wizja rzucona na płótno.

${ }^{49}$ Byli to według wspomnień Rity Labrosse-Gombrowicz: Dubuffet, Józef Jarema, Maria Sperling, Kazimierz Głaz, Teresa Stankiewicz, nie licząc rzeźbiarzy, André Hayarta i Jamesa Ritchie; zob.: R. Gombrowicz, Gombrowicz en Europe, 1963-1969, Paryż 1988, s. 313-314.

${ }^{50}$ Gombrowicz postanowił nauczyć się lubić malarstwo, wypożyczał więc dzieła od znajomych artystów. Obrazy zmieniały miejsce, kolekcja powiększała się, a jej zasadniczą część stanowiły dzieła Jaremy i Marii Sperling. W kolekcji Gombrowicza oprócz ich prac znajdowały się także dzieła Kazimierza Głaza i Teresy Stankiewicz. Teresa Stankiewicz (ur. 1928), krakowska malarka była na stypendium w Fundacji Károlyi'ego w Vence w 1965 roku. Zaprzyjaźniła się z Gombrowiczem i miała okazje prowadzić z nim rozmowy o sztuce. Zostały przez nią spisane we wspomnieniach zatytułowanych „Spotkania z Gombrowiczem” (mps); zob.: P. Millati, Gombrowicz i malarstwo, [w:] Sonorité visuelle, s. 25-37. 
oświetlenia, a także i sąsiedztwa. Po otrzymaniu kolejnego obrazu od Marii Sperling pisał do artystki:

Twoje malowidło już powieszone, ja wolałem tamto, ale to ma zaletę, że podnieca się w kolorze z czerwieniami Giuseppe [Józefa Jaremy — M. Ch.-F.] więc zawiesiliśmy u Rity, gdzie Giuseppe ma najlepsze światło, a bez tego ani rusz, bo żaden obraz tak światła nie potrzebuje, jak ten. Dość, że oba razem silnie grają. Każde na osobnych skrzypcach $^{51}$.

Gombrowicz cenił i podziwiał prace Marii Sperling, miał w swojej kolekcji jej obrazy, kolaże, a także gobelin. Umiał bardzo trafnie określić specyfikę artystycznego duetu Jarema-Sperling. „Każde na osobnych skrzypcach”. Charakterystyczne jest, że odniósł się tu do swej wielkiej fascynacji, jaką była muzyka, by opisać brzmienie dwóch wiszących u niego obrazów. Być może klucz do tajemnicy jego przyjaźni z Marią Sperling, artystką, przypomnijmy, posiadającą studia pianistyczne, tkwił właśnie w owej wrażliwości na kompozycję, pojętą w sensie muzycznym, ale też zrozumianą, jako siła twórcza, która porządkuje formę i która leży u podstaw każdego dzieła sztuki. Maria Sperling tworzyła na południu Francji przez ponad trzydzieści lat. Jej dzieła znajdują się w Muzeum Picassa w Antibes, w Muzeum Sztuki Współczesnej w Nicei, a także w Paryżu ${ }^{52}$. Polskie kolekcje są nieco bogatsze - Muzeum Narodowe w Krakowie oraz Muzeum Sztuki w Łodzi posiadają prace artystki. Największe zbiory posiada Muzeum Historyczne w Sanoku, oprócz prac Jaremy i Marii Sperling otrzymało także archiwa, a w tym listy Jaremy do Marii Sperling. Po śmierci Jaremy w 1975 roku, Maria Sperling przeniosła się do Paryża. Wystawiała w paryskich galeriach, była oddana sztuce do końca. Pytana o to czy w jej życiu ,,artystka nie skradła miejsca kobiecie” odpowiadała, że:

można być kobietą, matką i artystką. Oczywiście, trzeba móc to zrobić. Trzeba najpierw mieć silną wolę i wiedzieć, czego się chce w życiu. Zorganizowałam moje życie w taki właśnie sposób ${ }^{53}$.

Przyjaźń stojących u jej boku mężczyzn, Sperlinga architekta, potem Jaremy malarza, głębokie zrozumienie dla jej talentu sprawiły, że mogła wypełnić swe życie sztuką i odnieść sukces. Została przez krytykę zaliczona do grupy najlepszych współczesnych twórców ${ }^{54}$.

Kończąc niniejszy szkic należy zadać pytanie o miejsce kobiet zafascynowanych Południem we współczesnym malarstwie, w sytuacji, gdy przed artystami otwierają się niezliczone możliwości podróży, a w sztuce Francja i Paryż nie odgrywają już roli centralnej.

Tradycja plenerów i pracy w regionach tak atrakcyjnych jak śródziemnomorskie wybrzeże przetrwała, głównie dzięki malarzom ze środowiska krakowskiego. Grupa twórców wywodząca się z Akademii Sztuk Pięknych i uformowana przez pokolenie kolorystów podjęła tradycje plenerowe. Południe Francji odwiedza od lat Teresa Wallis (ur. 1926) wspólnie z mężem Juliuszem Joniakiem ${ }^{55}$. Podróże do Prowansji i do Hiszpa-

\footnotetext{
${ }^{51}$ Cyt. za: P. Millati, Gombrowicz i malarstwo, s. 34.

${ }^{52}$ Centre Pompidou w Paryżu posiada wykonany wspólnie przez Jaremę i Sperling gobelin.

${ }^{53}$ J. Selz, Marie Sperling, s. 19.

${ }^{54}$ To m.in. opinia znanego krytyka sztuki Pierre'a Courthion; zob.: P. Courthion, Marie Sperling, Paris 1980, s. 9.

${ }_{55}$ Teresa Wallis studiowała u Hanny Rudzkiej-Cybis, Czesława Rzepińskiego i Jerzego Fedkowicza; uzyskała dyplom w 1954 roku. Wybitny pedagog, pracuje i wystawia w Krakowie.
} 
nii, prowadzące przez znane już w malarstwie polskim Collioure, są dla niej stałym źródłem inspiracji. Notowane w szkicownikach prowansalskie pejzaże, miejskie sceny, fragmenty życia stanowią punkt wyjścia dla płócien powstających w podkrakowskiej pracowni. Artystka podchodzi z właściwym sobie dystansem do kuszącego intensywnym kolorytem południa. Wypowiada się w subtelnej, wyrafinowanej a czasem przygaszonej wręcz gamie barwnej. W jej spojrzeniu na południowy pejzaż wyczuwa się poszukiwania rytmu i porządku. Pociąga ją pejzaż miejski, krajobraz ze wszystkimi współczesnymi aspektami życia, ulicznym ruchem, znakami drogowymi, barwnym thumem turystów. Przedstawia także śródziemnomorski pejzaż bez sztafażu, surowy i ponadczasowy.

Wśród artystów najmłodszej generacji wybór Południa, jako miejsca, w którym pragną tworzyć, wiąże się z kontynuacją lub z poszerzaniem zakresu studiów. Polscy stypendyści chętnie wybierają szkoły o profilu artystycznym w Nicei, Marsylii czy Aix en Provence. Pragną czerpać ze śródziemnomorskiej tradycji, lecz także z nowych nurtów współczesnej sztuki. Aleksandra Czuja (ur. 1972) po ukończeniu studiów w warszawskiej akademii i w Ecole d'Art w Aix en Provence, w swym rozwoju artystycznym czerpała z osiągnięć grupy Supports/Surffaces i ze sztuki Claude'a Viallat, gdy idzie o ideę wkraczania dzieła sztuki w przestrzeń, która je otacza, o używanie szablonów, czy o kreowanie znaku-symbolu ${ }^{56}$. Fascynacja pejzażem prowansalskim, naturalnym porządkiem obserwowanym w naturze, w gajach oliwnych czy winnicach, zaowocowała pracą nad znakiem, elementem konstrukcyjnym powtarzanym aż do wizualnego zatracenia pierwotnej formy — czaszki kozła — na rzecz nowego bytu, zrytmizowanej powierzchni malarskiej. Korzysta także z procederów wywodzących się z polskiej sztuki ludowej jak wycinanki czy tkactwo. Podkreśla wagę dwóch tradycji kulturowych obecnych w jej sztuce, śródziemnomorskiej, która tak silnie na nią oddziałuje, i polskiej, jako tej, z której sama się wywodzi. Jest rzeczą znamienną, że pracując poza krajem w sposób naturalny czerpie się z elementów świadczących o własnej tożsamości. Czyż polskie artystki z okresu międzywojennego nie zdobywały uznania za typowo polskie, w stylu i formie, prace? Kobiety artystki były często wyrazicielami owej polskiej tożsamości, niekiedy w większym stopniu niż ich koledzy artyści. To zapewne jeszcze jeden z aspektów sztuki kobiet, który wymagałby szerszego omówienia.

Wiek XX ze względu na szczególne zmiany społeczno-kulturowe był dla kobiet wiekiem sztuki. Polskie artystki aktywne we Francji, prowadząc codzienną walkę o własne, autentyczne malarstwo, wzbogacały naszą spuściznę kulturową o dzieła oryginalne i wybitne. Warto przypomnieć, że począwszy od pierwszego dziesięciolecia XX wieku działały także poza Paryżem, na południu. Polska obecność artystyczna w Prowansji na przestrzeni XX wieku była zjawiskiem stałym, choć często dotyczącym indywidualnych karier. W kontekście coraz szerzej zakrojonych badań nad sztuką polską we Francji, publikacji naukowych, wystaw oraz sesji poświęcanych sztuce kobiet, uzasadniona wydaje się konieczność ukazania także południowego dorobku naszych artystek, by uzyskać pełniejszy obraz ich wkładu w polską kulturę ${ }^{57}$.

${ }^{56}$ Claude Viallat, ur. w 1936 roku w Nîmes, współzałożyciel grupy Supports/Surfaces, pedagog, wykładowca w szkołach sztuk pięknych w Nicei, Marsylii, Paryżu, dyrektor Ecole des Beaux-Arts w Nîmes.

${ }^{57}$ Zob.: J. M. Sosnowska, Poza kanonem. Sztuka polskich artystek 1880-1939, Warszawa 2003; Artystki polskie, red. A. Jakubowska, Warszawa 2011. Niezwykle istotny wkład w wiedzę o polskich twórczyniach stanowiła międzynarodowa sesja naukowa „Artystki polskie w środowisku paryskim: wokół Alicji Halickiej”. Villa la Fleur, Konstancin-Jeziorna, 23 września 2011. Autorzy projektu: M. A. Supruniuk, E. Bobrowska, A. Winiarski. Wystawie dzieł A. Halickiej 


\section{IS THERE ONLY PARIS? A FEW REMARKS ABOUT POLISH FEMALE ARTISTS IN SOUTHERN FRANCE}

Since the first decade of the $20^{\text {th }}$ century, Polish female artists, active in France, have also worked outside of Paris, in Southern France. Struggling every day for their own authentic art of painting, they enriched the Polish cultural heritage with original and exceptional works originating from various stylistic currents. The article brings a description, in a chronological order, of the contribution of many famous painters, such as Mela Muter, to Polish culture in the $20^{\text {th }}$ century. It also reminds lost works of artists in the South of France, somewhat forgotten nowadays.

KEY WORDS: Polish female artists; Polish painting in the $20^{\text {th }}$ century; Polish female artists in Southern France; artistic journeys; Polish artistic colony in Southern France; Mela Muter; Het Kwiatkowska; Dora Bianka; Maria Sperling.

(1894-1975) w Villi la Fleur towarzyszyła publikacja: K. Zagrodzki, Mistrzowie Ecole de Paris: Alicja Halicka, Warszawa 2011. 